A vailable online at http://jddtonline.info

RESEARCH ARTICLE

\title{
EFFECT OF FLAVANOID RICH FRACTION OF CITRUS MEDICA LINN. ON ETHYLENE GLYCOL INDUCED UROLITHIASIS IN RATS
}

\author{
*Chavada Kal peshsinh S, Fadadu Kumar N, Patel Kirti V, Patel Kalpana G, Gandhi Tejal R \\ Anand Pharmacy College, Anand, Gujarat-388001, India \\ Corresponding Author's Email: kalpeshsinhchavada@gmail.com
}

Received 06 June 2012; Review Completed 26 June 2012; Accepted 05 July 20122012, Available online 15 July 2012

\begin{abstract}
Ethylene glycol $(0.75 \%$ v/v p.o. in drinking water; 28 days) induced urolithiasis was used to study the protective effect of flavanoid rich fraction of Citrus medica Linn. (FFCM) at three dose level $(320 \mu \mathrm{g} / \mathrm{kg} ; 380 \mu \mathrm{g} / \mathrm{kg} ; 440 \mu \mathrm{g} / \mathrm{kg}$ - 28 days; p.o.) in male wistar albino rats $(250-300 \mathrm{~g} ; \mathrm{n}=6 /$ group $)$. Cystone $(750 \mathrm{mg} / \mathrm{kg}$; p.o.) was used as standard drug. After completion of treatment period of 28 days, $24 \mathrm{hr}$ urine sample and blood were collected. Various physical parameters like body weight, diuresis, $\mathrm{pH}$, kidneys weight (wet and dry) were measured. Various stone forming inhibitors (Magnesium and Citrate) and promoters (Oxalate, Calcium, Phosphate, Uric acid and Urea) were analysed in urine, serum and kidn ey homogenate. Renal function test (BUN and Creatinine clearance), antioxidant parameters (MDA and Catalase) and crystalluria were also evaluated. FFCM at all dose level significantly prevented EG induced changes in calcium, inorganic phosphate, uric acid, oxalate, urea, citrate, magnesium level; creatinine clearance and oxidative stress. FFCM possess anti-lithiatic activity in experimentally induced urolithiatic model (Ethylene glycol model), that can be attributed to its diuretic action, decrease in promoters and increase in inhibitors level \& antioxidant potential.
\end{abstract}

Key words: Urolithiasis, Citrus medica Linn., Calcium oxalate, Ethylene glycol.

\section{INTROUCTION}

Urolithiasis has afflicted humankind since antiquity and can persist, with serious medical consequences, throughout a patient's lifetime. Last five decades have observed an increase in the stone formations (either in kidney \&/or in any part of urinary tract including ureters \&/or bladder) and has hence led to increased quest towards the therapeutics of urolithiasis. ${ }^{\mathbf{1 , 2}}$ In this pursuit it has been recognized that crystal formation in urine is the first step in stone disease, and is substantiated by significant evidences of most calculi arising in the urinary system from a common component of urine, e.g. calcium oxalate $(\mathrm{CaOx})$, representing up to $80 \%$ of analysed stones. ${ }^{\mathbf{3 , 4}}$ To worsen up the scenario the recurrence of urolithiasis represents a serious problem, as patients who have formed a stone are more likely to form another, and thus stone prevention is highly recommended. ${ }^{\mathbf{5 , 6}}$

Various therapeutic strategies including diet management(Increased fluid intake, Fibers, Advice regarding calcium intake, Oxalate restriction, Reduced intake of vitamin C), diuretics (hydrochlorothiazide, chlorthalidone, Indapamide, Amiloride), expulsion therapy(Calciu m channel blockers, Steroids, Nonsteroidal anti-inflammatory drugs (NSAIDs), $\alpha 1$-adrenergic receptor antagonists), chelating agents(Magnesium, Citrates, Magnesium Citrate) and probiotic therapy have been used either alone or in combinations to have effective treatment against urolithiasis. These medicines have therapeutic benefits, but are plagued by their own pharmacological limitations and number of side effects (deep vein thrombosis, tremor, headache, palpitations, edema, nausea, vomiting, and loss of taste, hallucinations, rash, diarrhea, alopecia, abdominal pain, and anemia) on long term and combination use. Moreover the scientific evidence for their efficacy is less convincing. ${ }^{7}$
Currently, Extracorporeal Shock-Wave Lithotripsy (ESWL) is the standard procedure for eliminating kidney stones. However, in addition to the traumatic effects of shock waves, persistent residual stone fragments, and the possibility of infection, suggest that ESWL may cause acute renal injury, a decrease in renal function and an increase in stone recurrence. ${ }^{\mathbf{8 , 9}}$

Recent studies have shown that the use of phytotherapy along with the watchful waiting approach can reduce the symptoms of urolithiasis and facilitate stone expulsion. ${ }^{10,11,12}$ World Health Organisation (WHO, 2002) has also emphasised development of herbal drugs and traditional medicines for the benefit of the world population, in terms of cost effectiveness and side effect of the drugs. Thus alternative treatment using phytotherapy has been sought; but as the twentieth century progressed an increased dichotomy has been arising between the drug recognized by modern medicine and traditional medicines. The former group mainly consists of single chemical entities which have undergone rigorous testing for safety and efficacy before being granted official recognition as medicines. In contrast to this, drugs used in traditional medicines are usually employed as crude extracts made with water or dilute alcohol, and have little history of scientific testing for efficacy or safety. ${ }^{\mathbf{1 3}, 14}$

Thus there is need for isolation, standardization and evaluation of bioactive constituents from herbs and revolutionize the use of phytogenetic agents in modern therapy.

In the light of above facts Cirtrus medica Linn. (familyRutaceae), commonly known as 'bijoru', was selected for the study. This plant is of ancient origin. The more accredited provenance is from India but it probably arrived 
in Italy through the Hebrews who introduced the cultivation of the Diamante citron on the Calabrian coasts. ${ }^{15}$ The unripe fruits of Citrus medica are big, with a thin, smooth, and lemon-yellow peel and the pulp does not yield much juice. Bijoru has been claimed in traditional literature to be valuable against kidney stone. The peel of Citrus fruits has been used in traditional Asian medicine for centuries for Anti-inflammatory, Anti-oxidant, Antibiotic, cures polyuria, heals urinary calculi, and as antidote. ${ }^{16,17}$ No studies have so far been conducted on biological activity of chemical composition of flowers, leaves and fruits. ${ }^{\mathbf{1 8}}$ The diuretic and antioxidant potential of Citrus medica has also been reported by Federica et al,2011. Citrus medica fruits are also known to contain flavanoids, phenols, citric acid, essential oil, Limonene and y-terpinene. Among all of these constituents, flavanoids are reported for antiurolithiatic action. ${ }^{19}$ However, no systematic pharmacological study has reported the antiurolithiatic property of isolated flavanoid rich fraction of whole unripe Citrus medica Linn. Current study is an attempt to assess the effectiveness of flavanoid rich fraction of Citrus medica Linn. in experimentally induced urolithiasis in rats.

\section{MATERIALS AND METHODS:}

\section{Plant material:}

Fresh unripe fruits of Citrus medica Linn.were collected from the National Research Centre for Medicinal and Aromatic Plants (NRCMAP), Boriavi, Anand, Gujarat, India. Fruits were identified \& authenticated by expert Dr. Geetha K. A. , Senior Scientist (Plant Breeding) at NRCMAP, Boriavi, Anand, Gujarat, India.

\section{Preparation and Standardization of test drug}

The whole unripe fruits of Citrus medica Linn.was cut into small pieces and blended into fruit juicer. It was standardized by parameters such as $\mathrm{pH}$, Viscosity, Colour, Odour. ${ }^{20}$

\section{Isolation of flavonoids ${ }^{20,21}$}

Step-1: A small amount (20g) of whole unripe fruits of Citrus medica Linn.was cut into small pieces and blended into fruit juicer. It was immersed in $200 \mathrm{ml}$ of methanol (20\%) and heated on a hot water bath for $4 \mathrm{hrs}$ with continuous stirring at $55^{\circ} \mathrm{C}$. The cooled extract was then filtered and the filtrate was then reduced to $40 \mathrm{ml}$ on a waterbath at $90^{\circ} \mathrm{C}$. The methanolic aqueous extract was then transferred into $250 \mathrm{ml}$ separating funnel with $20 \mathrm{ml}$ diethyl ether and was shaken vigorously. The aqueous layer was recovered and ether layer was discarded. Purification process was repeated with another $20 \mathrm{ml}$ diethyl ether. $60 \mathrm{ml} \mathrm{n}$-butanol was added to the combined methanolic aqueous extract.

Step-2: Butanolic fraction was discarded and methanolic aqueous fraction $(40 \mathrm{ml})$ was collected and evaporated to $20 \mathrm{ml}$. To this was added $100 \mathrm{ml}$ of $2 \mathrm{M} \mathrm{HCl}$ and heated for 30-40 min at 100.C. The cooled extract was then extracted with $30 \mathrm{ml}$ of ethylacetate. The ethylacetate layer was then separated and concentrated to dryness by evaporation at $55^{\circ} \mathrm{C}$ on a water bath to collect precipitate $(2 \mathrm{~g}, 10 \% \mathrm{w} / \mathrm{w})$. The collected ethylacetate precipitate of Citrus media was qualitatively checked for the presence of flavanoids by TLC $^{22}$ and shinoda test. ${ }^{23-25}$ The flavanoid rich fraction of Citrus medica thus obtained was stored in a cool \& dry place and labelled as FFCM till further use.

\section{Animal source}

Healthy male Wistar Albino rats (250-300 g, 5-10 week age) were used in the experiments. The animals were acclimatized to standard laboratory conditions (temperature: $22 \pm 5{ }^{\circ} \mathrm{C}$ ), humidity $(55 \pm 5 \%)$ and maintained on 12-h light: 12-h dark cycle. They were provided with regular rat chow and drinking water ad libitum. The experimental protocol was approved by Institutional Animal Ethical Committee (IAEC) of Anand Pharmacy College (Registration no. 277/CPCSEA) as per the guidance of Committee for the Purpose of Control and Supervision of Experiments on Animals (CPCSEA), Ministry of Social Justice and Empowerment, Government of India.

\section{Dose fixation studies}

Dose fixation study was carried out on the rats to find out the optimu m dose that was effective to produce the desired effect to carry out further study.

Five different doses of FFCM $(220 \mu \mathrm{g} / \mathrm{kg}, 260 \mu \mathrm{g} / \mathrm{kg}$, $320 \mu \mathrm{g} / \mathrm{kg}, 380 \mu \mathrm{g} / \mathrm{kg}, 440 \mu \mathrm{g} / \mathrm{kg}$ )were selected for dose fixation study. Three doses with better activity were selected for further study, viz. FFCM-1- $320 \mu \mathrm{g} / \mathrm{kg}$, FFCM-2- $380 \mu \mathrm{g} / \mathrm{kg}$, FFCM-3- $440 \mu \mathrm{g} / \mathrm{kg}$.

\section{Ethylene glycol induced urolithi asis: ${ }^{26}$}

Ethylene glycol induced hyperoxaluria was used to assess the antilithiatic activity in albino rats. Healthy male wistar albino rats (36 rats) were divided in six groups containing six rats in each and the study was conducted for 28 days. Group I served as control and received regular rat food and drinking water ad libitum. Ethylene glycol $(0.75 \%)$ in drinking water was fed to Group II-VI for 28 days for induction of renal calculi. Additionally Group III received standard antiurolithiasis drug, cystone $(750 \mathrm{mg} / \mathrm{kg}$ body weight; p.o.), and Group IV, V and VI received FFCM (320 $\mu \mathrm{g} / \mathrm{kg}$; p.o., $380 \mu \mathrm{g} / \mathrm{kg}$; p.o.and $440 \mu \mathrm{g} / \mathrm{kg}$; p.o.) respectively for 28 days once daily.

\section{Assessment of antiurolithiatic acti vity}

\section{A) Collection of biological samples}

All animals were kept in individual metabolic cages with hydration of $15 \mathrm{ml}$ of water and urine samples of $24 \mathrm{~h}$ were collected on 28th day of study. Animals had free access to drinking water during the urine collection period. After urine collection, urine volume, $\mathrm{pH}$ of urine was measured ${ }^{27}$. Urine was analyzed for total excretion of Oxalate $^{\mathbf{3 0}}$,Calcium ${ }^{28}$, Phosphate ${ }^{31}$, Uric acid ${ }^{32}$, Urea ${ }^{34}$, Magnesium $^{29}$ and Citrate ${ }^{33}$. Presence of Crystalluria was also evaluated in the collected urine sample. ${ }^{35}$

\section{B) Serum analysis}

After the experimental period, on 29th day blood was collected retro-orbitally under anaesthetic condition. Serum was separated by centrifugation (Centrifuge, Plastograft industries Pvt. Ltd., R-4R-V/FA) at $4000 \mathrm{rpm}$ 
for $10 \mathrm{~min}$ and analyzed for Calcium ${ }^{28}$, Phosphate ${ }^{31}$, Uric $\operatorname{acid}^{32}$, Urea nitrogen ${ }^{34}$, Magnesium ${ }^{29}$ and Creatinine clearance $^{34}$.

\section{C) Kidney homogenate anal ysis ${ }^{38}$}

The abdomen was cut open to remove both kidneys from each animal. Isolated kidneys were cleaned off extraneous tissue and one of them was preserved in $10 \%$ neutral formalin. The other one was dried at $80^{\circ} \mathrm{C}$ in a hot air oven. A sample of $100 \mathrm{mg}$ of the dried kidney was boiled in $10 \mathrm{ml}$ of $1 \mathrm{~N}$ hydrochloric acid for $30 \mathrm{~min}$ and homogenized. The homogenate (EIE instruments Pvt. Ltd., 0603121) was centrifuged (Centrifuge, Plastograft industries Pvt. Ltd., R-4R-V/FA) at $2000 \mathrm{rpm}$ for $10 \mathrm{~min}$ and the supernatant was separated ${ }^{\mathbf{3 6}}$. The calcium ${ }^{\mathbf{2 8}}$, oxalate $^{30}$, phosphate $^{31}$, Uric acid ${ }^{32}$ and protein ${ }^{37}$ content in kidney homogenate were determined.

\section{D) Histopathology}

Kidney samples were weighed and fixed rapidly with $10 \%$ neutralized formalin ( $\mathrm{pH}$ 7.4). Sections of kidney fixed in paraffin were prepared and stained with hematoxylin and eosin and observed for pathological changes.

\section{Statistical anal ysis ${ }^{39}$}

All the raw data were recorded in appropriate formats and summarized in tabular form, wherever necessary. Numerical results were processed to get group mean and standard error mean. Statistical analysis was performed using Graph Pad Pris m Version 5.00.v. ANOVA (Analys is of Variance) was used for the comparison of different dosage groups with the model group for different parameters. Comparison of dosage groups with the model group was done on the basis of individual group data. Post hoc test to analyze data after ANOVA was done using Dunnett's test (parametric).

\section{RES ULTS}

To maintain reproducibility of the extrac, juice obtained from fresh unripe fruits of Citrus medica was always standardized with reference to parameters like $\mathrm{pH}$ (4.5), colour (pale yellow green), taste (sour) and viscosity (12.6 cp). Calculated yield of the flavanoid rich fraction of Citrus medica was $48 \mathrm{mg} / 500 \mathrm{~g}$. To the aliquots $(2 \mathrm{ml})$ of extract of fraction magnesium chloride was added and $1 \mathrm{ml}$ of conc. $\mathrm{HCl}$ were added. The change in the color of the sample from reddish brown to cherry red color indicated the presence of flavanoid. The presence of flavaoid was confirmed by thin layer chromatography [mobile phase : Toluene: Ethyl acetate: Formic acid (36:12:5) ]which showed a pale yellow colored band (Rf value 0.66 ) when derivitized with ammonia vapour.

From the dose fixation study three doses with better activity were selected for further study, viz. FFCM-1- 320 $\mu \mathrm{g} / \mathrm{kg}$, FFCM-2- $380 \mu \mathrm{g} / \mathrm{kg}$, FFCM-3- $440 \mu \mathrm{g} / \mathrm{kg}$.

There was a significant decrease in animal weight and urine volume per day and increase in the dry and wet kidney weight in ethylene glycol calculi-induced model control animals as compared to normal control animals (Table-1, Group I \& Group II). These changes were significantly prevented by treatment with Cystone and FFCM (Table-1, Group III \& Group IV-VI). Urinary pH was found to be acidic in normal control and model control animals. Treatment with cystone and FFCM (Table-1, Group III \& Group IV-VI) significantly increased urinary $\mathrm{pH}$ value.

In the present study, chronic administration of $0.75 \%(\mathrm{v} / \mathrm{v})$ ethylene glycol aqueous solution to male wistar rats resulted in hyperoxalouria. Stone forming promoters like Oxalate, Calcium, Phosphate, Uric acid, and Urea excretion were grossly increased in calculi-induced model control animals (Table-1, Group II). Both Cystone and FFCM treatment significantly $(\mathrm{P}<0.05)$ lowered the elevated levels of these stone forming promoters in urine (Table-1, Group III \& IV-VI) as compared to calculiinduced model control an imals.

The deposition of the crystalline components like calcium, phosphate and uric acid in the renal tissue (kidney homogenate) was increased in calculi-induced model control animals (Table-1, Groups II). Both Cystone and FFCM treatment significantly $(\mathrm{P}<0.05)$ reduced the kidney homogenate content of these stone forming constituents (Table-1, Group III \& IV).

The serum calcium, phosphate, uric acid and BUN were remarkably increased in calculi -induced animals (Table-1, Group II) while creatinine clearance was decreased in group II when compared with control animals, indicating marked renal damage. However treatment with Cystone and FFCM treatment significantly $(\mathrm{P}<0.05)$ lowered the serum levels of calcium, phosphate, uric acid, BUN and improved creatinine clearance (Table-1, Group III \& IV).

At the end of 28 day treatment significant reduction in citrate level and magnesium levels were observed in urine samples in calculi-induced model control animals (Table1, Group II). Both Cystone and FFCM treatment showed improvement in the levels of magnesium and citrate in urine (Table-1, Group III \& IV) as compared to calculiinduced model control animals. However the elevations in citrate levels in FFCM treatment groups was nonsignificant.

Microscopic observation at $100 \mathrm{X}$ of urine for presence of crystalluria revealed the presence of crystals in model group (" $+++">20$ crystals per high power field) which was significantly higher than the crystals observed in control animals ("+" 1 to 5 crystals per high power field). Treatment with cystone, FFCM-2 and FFCM-3 significantly $(\mathrm{p}<0.05)$ reduced this crystalluria as "+" 1 to 5 crystals per high power field, where as FFCM-1 non significantly reduced this crystalluria as "++" 6 to 20 crystals per high power field, in urine. (Table-2) 
Table 1 Effect of FFCM on various physical parameters in ethylene glycol induced urolithiasis.

\begin{tabular}{|c|c|c|c|c|c|c|}
\hline Parameters & $\begin{array}{l}\text { Group-I } \\
\text { (Control) }\end{array}$ & $\begin{array}{c}\text { Group-II } \\
\text { (Model) }\end{array}$ & $\begin{array}{l}\text { Group-III } \\
\text { (Standard) }\end{array}$ & $\begin{array}{l}\text { Group-IV } \\
\text { (FFCM-1) }\end{array}$ & $\begin{array}{c}\text { Group-V } \\
\text { (FFCM-2) }\end{array}$ & $\begin{array}{l}\text { Group-VI } \\
\text { (FFCM-3) }\end{array}$ \\
\hline \multicolumn{7}{|c|}{ PHYS ICAL PARMETERS } \\
\hline $\begin{array}{l}\text { Percentage Change In Body Weight } \\
(\%)\end{array}$ & $0.62 \pm 0.469$ & $-1.62^{\#} \pm 0.22$ & $1.21^{*} \pm 0.5$ & $0.79^{*} \pm 0.192$ & $1.33^{*} \pm 0.327$ & $1.78^{*} \pm 0.189$ \\
\hline Urine volume (ml) & $14.5 \pm 1.774$ & $6.88^{\#} \pm 1.157$ & $8.8 \pm 1.581$ & $11.2 \pm 2.365$ & $13.5 \pm 1.783$ & $\begin{array}{l}19.13 \pm 1.54 \\
6\end{array}$ \\
\hline Wet kidney weight (g) & $1.33 \pm 0.157$ & $3.26^{\#} \pm 0.207$ & $1.93 \pm 0.201$ & $2.01 \pm 0.535$ & $1.67 \pm 0.329$ & $1.13 \pm 0.067$ \\
\hline Dry kidney weight (g) & $1.11 \pm 0.126$ & $3.04^{\#} \pm 0.223$ & $1.66^{*} \pm 0.185$ & $1.69^{*} \pm 0.41$ & $1.34^{*} \pm 0.333$ & $0.88^{*} \pm 0.053$ \\
\hline Urine $\mathrm{pH}$ & $4 \pm 0.194$ & $2.34^{\#} \pm 0.139$ & $4.8 \pm 0.192$ & $5.4 \pm 0.658$ & $6.48^{\prime \prime} \pm 0.088$ & $5.72 \pm 0.694$ \\
\hline \multicolumn{7}{|c|}{ PROMOTERS } \\
\hline \multicolumn{7}{|l|}{ IN URINE SAMPLE } \\
\hline Oxalate (mg/dl) & $7.64 \pm 1.019$ & $11.44^{\#} \pm 1.824$ & $7.57 \pm 0.774$ & $9.30 \pm 1.047$ & $6.95 \pm 0.667$ & $6.65 \pm 0.501$ \\
\hline Calcium (mg/dl) & $12.59 \pm 1.633$ & $21.45^{\#} \pm 1.232$ & $11.73^{*} \pm 1.236$ & $16.1^{\prime \prime} \pm 1.225$ & $14.53 \pm 1.258$ & $13.64^{\prime \prime} \pm 1.066$ \\
\hline Phosphate (mg/dl) & $58.50 \pm 1.357$ & $71.27^{\#} \pm 1.388$ & $59.72 \pm 1.310$ & $51.10 " \pm 2.008$ & $44.74 \pm 1.000$ & $41.34 " \pm 0.897$ \\
\hline Uric acid $(\mathrm{mg} / \mathrm{dl})$ & $7.03 \pm 0.657$ & $9.26^{\#} \pm 0.392$ & $3.65^{*} \pm 0.508$ & $5.31^{*} \pm 0.599$ & $4.44^{*} \pm 0.505$ & $3.79^{*} \pm 0.531$ \\
\hline Urea(mg/dl) & $111.53 \pm 0.945$ & $161.89 \pm 1.75 \#$ & $60.53 \pm 1.329^{*}$ & $95.20 \pm 0.658^{*}$ & $\begin{array}{l}90.46 \pm 1.082 \\
*\end{array}$ & $88.42 \pm 0.523^{*}$ \\
\hline \multicolumn{7}{|l|}{ IN SERUM SAMPLE } \\
\hline Calcium $(\mathrm{mg} / \mathrm{dl})$ & $7.80 \pm 1.415$ & $12.95^{\#} \pm 1.454$ & $6.75^{*} \pm 0.683$ & $13.01 \pm 1.680$ & $11.17 \pm 1.083$ & $11.37 \pm 0.765$ \\
\hline Phosphate (mg/dl) & $5.72 \pm 0.526$ & $9.48^{\#} \pm 1.400$ & $5.96 \pm 0.883$ & $7.37 \pm 1.193$ & $6.20 \pm 0.969$ & $5.98 \pm 0.817$ \\
\hline Uric acid $(\mathrm{mg} / \mathrm{dl})$ & $4.35 \pm 0.387$ & $7.02^{\#} \pm 0.369$ & $6.38 \pm 0.495$ & $4.86^{\prime \prime} \pm 0.611$ & $3.76 \pm 0.554$ & $3.38^{\prime \prime} \pm 0.443$ \\
\hline \multicolumn{7}{|l|}{ IN KIDNEY HOMOGENATE } \\
\hline Calcium & $4.28 \pm 1.490$ & $23.40^{\#} \pm 1.343$ & $15.43 \pm 1.408$ & $14.14 \pm 1.387$ & $12.77^{\prime \prime} \pm 1.100$ & $9.51 \pm 1.267$ \\
\hline Phosphate (mg/dl) & $0.578 \pm 0.057$ & $0.82^{\#} \pm 0.060$ & $0.42 \pm 0.054$ & $0.61 \pm 0.014$ & $0.55^{\prime \prime} \pm 0.010$ & $0.49^{\prime \prime} \pm 0.011$ \\
\hline Uric acid $(\mathrm{mg} / \mathrm{dl})$ & $3.57 \pm 0.313$ & $4.30^{\#} \pm 0.647$ & $3.77 \pm 0.535$ & $4.19 \pm 0.618$ & $4.23 \pm 0.588$ & $3.75 \pm 0.391$ \\
\hline \multicolumn{7}{|c|}{ INHIB ITORS } \\
\hline \multicolumn{7}{|l|}{ IN URINESAMPLE } \\
\hline Magnesium (mEq/dl) & $2.56 \pm 0.313$ & $1.69^{\#} \pm 0.208$ & $2.13 \pm 0.261$ & $1.94 \pm 0.073$ & $2.67 \pm 0.260$ & $3.25 \pm 0.363$ \\
\hline Citrate $(\mathrm{mg} / \mathrm{dl})$ & $0.38 \pm 0.026$ & $0.26^{\#} \pm 0.034$ & $0.17^{*} \pm 0.013$ & $0.22 \pm 0.008$ & $0.19 \pm 0.013$ & $0.17^{*} \pm 0.014$ \\
\hline \multicolumn{7}{|l|}{ IN SERUM SAMPLE } \\
\hline Magnesium (mEq/dl) & $1.19 \pm 0.067$ & $0.60^{\#} \pm 0.021$ & $0.81 \pm 0.020$ & $1.17^{*} \pm 0.040$ & $1.57 \pm 0.036$ & $2.01 " \pm 0.034$ \\
\hline \multicolumn{7}{|c|}{ KIDNEY FUNCTION TEST ( in serum samples) } \\
\hline Urea (mg/dl) & $14.34 \pm 0.957$ & $38.76^{\#} \pm 1.262$ & $18.26 \pm 1.398$ & $15.17 \pm 0.618$ & $12.32 \pm 0.555$ & $10.36 \pm 0.949$ \\
\hline Creatinine clear ance $(\mathrm{ml} / \mathrm{min})$ & $0.038 \pm 0.004$ & $0.007^{\#} \pm 0.0005$ & $0.009 \pm 0.0003$ & $0.005 \pm 0.0003$ & $0.003 \pm 0.0002$ & $\begin{array}{l}0.003 \pm 0.000 \\
2\end{array}$ \\
\hline
\end{tabular}

Table 2 Effect of IFFCM on Crystalluria in EG model

\begin{tabular}{|l|c|c|c|c|c|c|}
\hline Parameter & $\begin{array}{c}\text { Group-I } \\
\text { (Control) }\end{array}$ & $\begin{array}{c}\text { Group-II } \\
\text { (Model) }\end{array}$ & $\begin{array}{c}\text { Group-III } \\
\text { (Standard) }\end{array}$ & $\begin{array}{c}\text { Group-IV } \\
\text { (FFCM-1) }\end{array}$ & $\begin{array}{c}\text { Group-V } \\
\text { (FFCM-2) }\end{array}$ & $\begin{array}{c}\text { Group-VI } \\
\text { (FFCM-3) }\end{array}$ \\
\hline $\begin{array}{l}\text { No. Of crystals } \\
\text { per high power } \\
\text { feild }\end{array}$ & + & +++ & + & ++ & + & + \\
\hline
\end{tabular}

Histopathological studies of kidneys revealed that the tissue samples from the control group shows tubules with single epithelial lining along the margin and were of normal size. In model group, much tubular dilatation with flattening of renal tubular epithelial cells in the renal cortex with tubular necrosis and interstitial inflammatory infiltrate due to crystal deposits inside the tubules was observed. But kidney specimen from FFCM-2 and FFCM3 treated groups showed characters similar to the normal control group, while cystone and FFCM-1 treated group showed less dilation of tubules and crystals deposition as compared to model group. (Figure-1)

\section{DISCUSS ION}

Calcium oxalate $(\mathrm{CaOx})$ is the main constituent (up-to $80.0 \%$ ) in majority of kidney stones followed by $1.0 \%$ to $10.0 \%$ of calcium phosphate; about $10.0 \%$ of struvite, $9.0 \%$ uric acid and the remaining $1.0 \%$ are composed of cysteine or drug-related stones. Thus the present study, targeted ethylene glycol induced $\mathrm{CaOX}$ growth and complexation. Selection of male rats for the induction of urolithiasis was driven by the fact that the urinary system of male rats resembles that of humans ${ }^{\mathbf{4 0}}$ and increased amount of stone deposition in male Wistar Albino rats as compared to female of the same species in various previously conducted scientific studies. ${ }^{\mathbf{4 1}}$ 


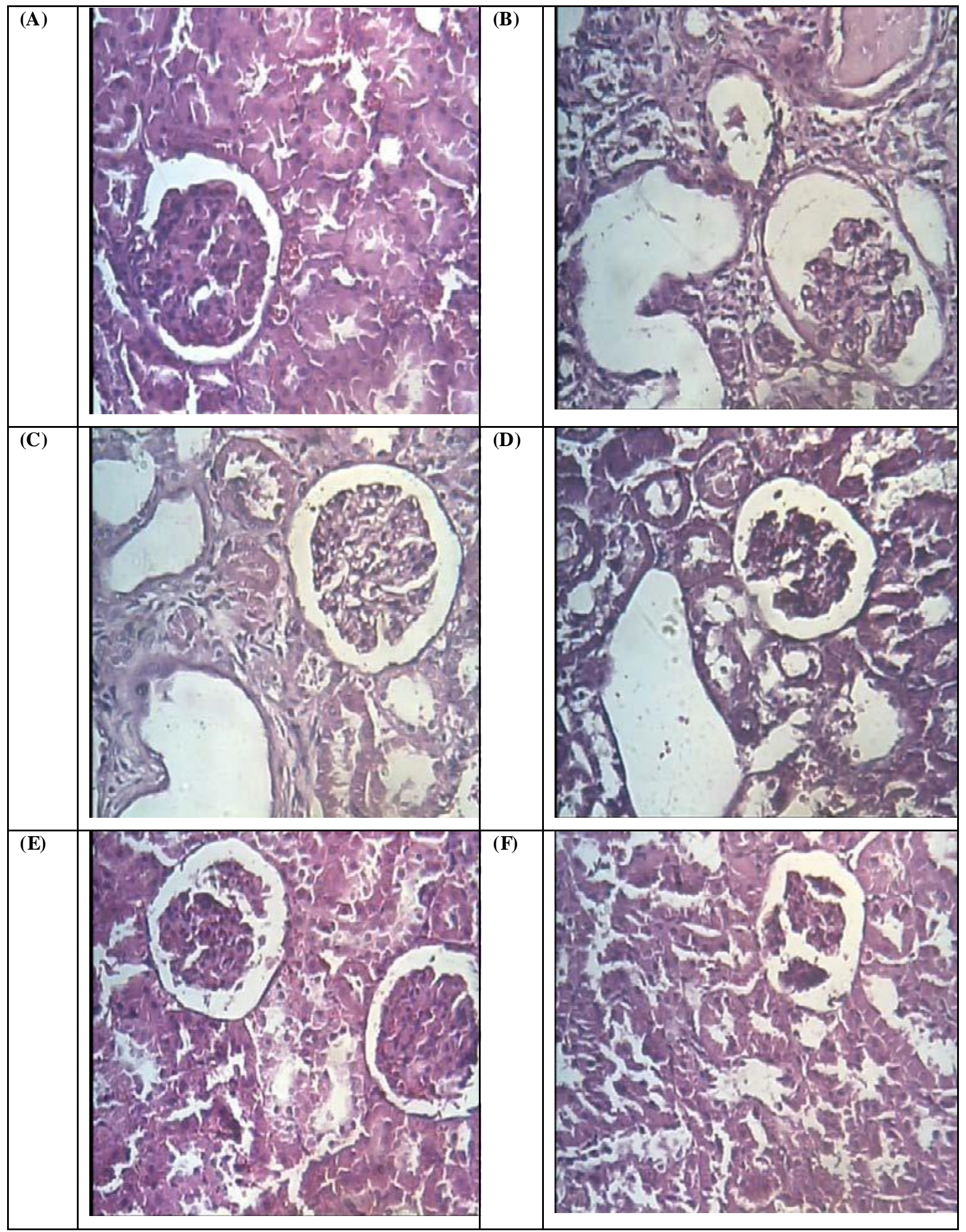

Figure 1: Effect of FFCM on His topathology of rats' kidney

Histopathology of rat kidney section. (A) Control group: Nomal renal tubules with no dilation and inflammation; (B) Model group (EG): Marked tubules dilation with interstitial inflammatory infiltrate due to crystal deposits; $(C) \boldsymbol{E} \boldsymbol{G}+\boldsymbol{S T D}$ : less tubules dilation with interstitial inflammatory infiltrate compared to model group; (D) EG+FFCM-1: same changes as seen with std group; (E) EG+FFCM-2: same as control group $(F) \boldsymbol{E G + F F C M - 3 : ~ s a m e ~}$ as control group; (haematoxylin and eosin, original magnification X400).

Calcium and oxalate are the major promoters of kidney stone formation. Urinary super-saturation with respect to stone-forming constituents is generally considered to be one of the causative factors in calculogenesis. Specifically oxalate metabolis $\mathrm{m}$ in humans and rats is considered to be (C) 2011, JDDT. All Rights Reserved similar, ${ }^{\mathbf{4 2}}$ and chronic mild hyperoxaluria can cause $\mathrm{CaOx}$ stone formation in humans and rats ${ }^{\mathbf{4 3}, 4}$. It is accepted that hyperoxaluria is a far more significant risk factor in the pathogenesis of renal stones than hypercalciuria. Evidence in previous studies indicated that in response to 28 day 
period of ethylene glycol $(0.75 \%, \mathrm{v} / \mathrm{v})$ administration, young male albino rats form renal calculi composed mainly of calcium oxalate. ${ }^{\mathbf{4 5 - 4 7}}$ The biochemical mechanis ms for this process are related to rapid absorption and metabolization in the liver of ethylene glycol via alcohol dehydrogenase or aldehyde dehydrogenase to glycolic acid. Glycolic acid is oxidized to glyoxylic acid, which is further oxidized to oxalic acid by glycolate oxidase or lactate dehydrogenase. Thus increase in the urinary concentration of oxalate in ethylene glycol fed animals promotes hyperoxaluria, resulting in stone formation. ${ }^{47}$ In present study feeding of $0.75 \%$ EG through drinking water markedly increase the oxalate level in urine in model group. The treatment with cystone, FFCM-1, FFCM-2 and FFCM-3 significantly prevented this rise in oxalate levels in urine as compared to model group. Decreased excretion of oxalate may be due to the regulation of oxalate metabolis $\mathrm{m}$ and oxalate anion transporter SLC26A6 (CFEX) in renal tubules.

Secondly increased urinary calcium is a factor favoring the nucleation and precipitation of calcium oxalate or apatite (calcium phosphate) from urine and subsequent crystal growth. Hypercalciuria can also decrease inhibitor function and lead to crystallization. Further more, cellu lar response to newly formed crystals and factors that modulate these crystal-cell interactions could stimulate the initiation of an intrarenal stone. ${ }^{48}$ Admin istration of EG caused decrease in urine $\mathrm{pH}$ with increased in serum, urine and kidney calcium levels thereby promoting formation of calcium oxalate stones. These effects were significantly prevented by urinary $\mathrm{pH}$ neutralizing effect and decreased calcium levels by cystone, FFCM-1, FFCM-2 and FFCM-3 treatment as compared to model group. Thus the FFCM possess the potential of inhibiting homogeneous crystal formation.

Urine is itself a supersaturated solution and only some individuals are prone to urolithiasis. Thus, a supersaturated condition alone is not enough to precipitate stone but crystallization and aggregation of these lithogenic substances leads to calculi formation. ${ }^{49}$ An increase in urinary phosphate is observed in calculi-induced rats (Group II). Increased urinary phosphate excretion along with oxalate stress seems to provide an environment appropriate for stone formation by forming calcium phosphate crystals, which epitaxially induces calcium oxalate deposition. ${ }^{\mathbf{5 0}}$ In the present study ethylene glycol intake leads to increase in inorganic phosphate. Treatment of FFCM restores phosphate level declined by ethylene glycol, thus reducing the risk of stone formation.

Increased Uric acid interferes with calcium oxalate solubility and it binds and reduces the inhibitory activity of glycosaminoglycans. ${ }^{51}$ The predominance of uric acid crystals in calcium oxalate stones and the observation that uric acid binding proteins are capable of binding to calcium oxalate and modulate its crystallization also suggests its primary role in stone formation. ${ }^{\mathbf{5 2}}$ In the present study, urinary uric acid concentration was increased in EG model group. The increase in uric acid excretion was significantly prevented by treatment with cystone, FFCM-1, FFCM-2 and FFCM-3 and thus

decreasing the crystal nucleation, aggregation and growth (Crystallization inhibition activity).

Increase in promoter's level after ethylene glycol ingestion leads to stone formation and aggregation in the kidney. Deposition of stone in to kidney resulted in the increase in weight of the dry kidney and wet kidney weight. ${ }^{\mathbf{5 3}}$ The results of the present study were consistent with the above reports. Treatment with std and test drugs improved all these changes significantly.

Intense pain associated with stone formation may lead to decrease in the food consumption which may result in decreased body weight. ${ }^{54} \mathrm{~A}$ decrease in body weight in the ethylene gylcol calculi-induced model control animals observed in the study supported the presence of stone formation. However, Cystone and FFCM treatment showed a good diuretic activity which might have prevented stone aggregation and thus relieved animals from pain. This may be reason of increased food consumption which leads to significant increase in body weight.

Citrate appears to alter both calciu m oxalate monohydrate and calcium phosphate crystallization. The most established effect of citrate in urine is to complex with calcium thereby reducing the concentration of $\mathrm{CaOx}$. This appears to be due to effects directly on the crystal surface rather than to an alteration of the availability of free calcium. Citrate is an inhibitor of calcium crystallization and has been shown to be an important inhibitor of $\mathrm{CaOx}$ agglomeration. ${ }^{\mathbf{5 5}}$ Stitchantrakul $\mathrm{W}$ et al $^{\mathbf{5 6}}$ also has reported that citrate is an important urolithias is inhibitor, which forms soluble complexes with calcium and inhibits precipitation and aggregation of calcium oxalate and phosphate. Citrate also increases the $\mathrm{CaOx}$ aggregation inhibitory activity of other urine macromolecules e.g. Tamm-Horsfall protein (THP) and may reduce the expression of urinary osteopontin (OPN), which is an important component of the protein matrix of urinary stones. Urinary citrate excretion can increase urinary $\mathrm{pH}$, which is a factor in the calcium-citrate-phosphate complex formation. ${ }^{57}$ Results of present study were in accordance to the above facts where by decrease in urinary citrate concentration in model animals was associated with decrease in urinary $\mathrm{pH}$ and increase in calcium oxalate stone formation. Treatment with FFCM-1 and FFCM-2 slightly imp roved the reduction in citrate excretion (though non-significant) and it may be due to the regulation of $\mathrm{Na} /$ Citrate co transporter in proximal tubules and thus balancing the Inhibitor and promoter of the crystallization in urine.

Many experimental studies have suggested that administration of magnesium salts prevents stone disease. ${ }^{\mathbf{5 8}}$ Magnesium can form complexes with oxalate and decrease supersaturation, consequently reducing the concentration available for $\mathrm{CaOx}$ precipitation. ${ }^{\mathbf{5 9}, \mathbf{6 0}}$ Oral intake of magnesium decreases the oxalate absorption and urinary excretion, in a manner similar to calcium by binding to oxalate in the gut. Magnesium supplementation in subjects with magnesium deficiency increases the excretion of citrate in urine. ${ }^{\mathbf{6 1}}$ Magnesium can reduce the super saturation of calcium oxalate and decrease the growth and nucleation rates of calcium o xalate crystals. In
CODEN (USA): JDDTAO 
the present study ethylene glycol administration significantly reduced magnesium concentration in urine. Treatment with FFCM prevented the urinary reduction in magnesium level ${ }^{62}$ which might have decreased supersaturation and consequently reduced $\mathrm{CaOx}$ precipitation.

Crystal's deposition in kidney decreases Glomerular Filtration Rate (GFR) due to the obstruction to the outflow of urine in urinary system, due to this the waste products, particularly nitrogenous substances such as urea, creatinine and uric acid get accumulated in blood. ${ }^{63}$ Even in the present study increase in BUN, serum uric acid and decrease in creatinine clearance was observed in model animals, suggesting damage to the glomerulus and kidney tubules. Treatment with FFCM-2 and FFCM-3 decreased BUN and uric acid. Increased in creatinine clearance was observed with treatment of cystone as compared to model group. These results reveal that FFCM may have improved renal function, which is in accordance with previous study that the impairment of renal function was prevented by the treatment of flavanoids. ${ }^{64}$

In the present study, urinary crystal analysis was performed for evaluating the presence of crystals without differentiating their poly morphic form. Rise in crystalluria was observed in model group which was significantly reduced by cystone, FFCM-1, FFCM-2 and FFCM-3 treatment which supported by the finding that Flavanois were reported to decrease $\mathrm{CaOx}$ crystal adhesion to renal epithelial cells by pre-coating the crystals. ${ }^{28}$

Histopathological examination of kidney sections derived from ethylene glycol induced urolithic rats showed polymorphic irregular crystal deposits inside the tubules which causes dilation of the proximal tubules along with interstitial inflammation that might be attributed to

\section{REFERENCES}

1. ShekarKumaran $\mathrm{M}$ and Patki P, "Evaluation of an ayurvedic formulation (cystone) in urolithiasis", European Journal of Integrative Medicine 2011, 23-28.

2. Crellin J, Good R and McGovern J. "The Aphorisms of Hippocrates", The Lancet 1998,259, 358, 110-112.

3. Levy F, Adams H and Pak C, "Ambulatory evaluation of nephrolithiasis: an update of a 1980 protocol', Am J Med. 1995-98, 5059.

4. Patankar S, Dobhada S, Bhansali M, Khaladkar S, and Modi J, "A prospective, randomized, controlled study to evaluate the efficacy and tolerability of Ayurvedic formulation "varuna and banana stem in the management of urinary stones", J Altern Complement Med. 2008, 14, 10, 1287-1290

5. Daudon M, Bader CA, Jungers $P$ "Urinary calculi. Review of classifications with etiology". Scanning Microsc 1993 ,1081-1086

6. Prien EL, Prien ELJ "Composition and structure of urinary stones. American Journal of Medicine"1968,654-672

7. Segura J, Preminger G, Assimos D, Dretler S, Kahn R and Lingeman J, "Ureteral Stones Clinical Guidelines Panel summary report on the management of ureteral calculi." Urol. 1997, 158, 1915-1921.

8. Kishimoto, T., Yamamoto, K., Sugimoto, T., Yoshihara, H., Maekawa, M., "Side effects of extracorporeal shock-wave exposure in patients treated by extracorporeal shock-wave lithotripsy for upper urinary tract stone". European Urology 1986, 308-313.

9. Begun, F.P., Knoll, C.E., Gottlieb, M., Lawson, R.K., "Chronic effects offocused electrohydraulic shock-waves on renal function and hypertension".The Journal of Urology 1991, 635-639.

10. Mukherjee P "Quality Control on Herbal Drugs." Eastern Publishers, Business Horizons Ltd 2002, 1-37.

11. De Smet P, "Herbal remedies", N Engl J Med. 2002, 347, 2046-2056. 12. Huxtable R, "The harmful potential of herbal and other plant products", Drug Saf. 1990, 1, 126-136 oxalate stones by Herniaria hirsuta on experimentally induced nephrolithiasis in rats". BJU international. 2003,137-40.

14. Petrovick P, Marques L, De Paula I. "New rules for phytopharmaceutical drug registration in Brazil". Journal of ethnopharmacology. 1999,51-5.

15. Conforti F, Statti GA, Tundis R, Loizzo MR, Menichini F. "In vitro activities of Citrus medica L. cv. Diamante (Diamante citron) relevant to treatment of diabetes and Alzheimer's disease". Phytotherapy Research. 2007,427-33.

16. Menichini F, Tundis R, Bonesi M, de Cindio B, Loizzo MR, Conforti $\mathrm{F}$, et al. "Chemical composition and bioactivity of Citrus medica L. cv. Diamante essential oil obtained by hydrodistillation, cold-pressing and supercritical carbon dioxide extraction". Natural Product Research. 2011,789-99

17. Kapadia GJ, Azuine MA, Tokuda H, Hang E, Mukainaka T, Nishino $\mathrm{H}$, et al. "Inhibitory effect of herbal remedies on 12-Otetradecanoylphorbol-13-acetate-promoted Epstein-Barr virus early antigen activation". Pharmacological research. 2002,213-20.

18. Federica M, Monica R, Marco B, Filomena C, DamianoD, Giancarlo A., Bruno d, Francesco M , Rosa T, Phytochemical profile, antioxidant, anti-inflammatory and hypoglycemic potential of hydroalcoholic extracts from Citrus medica L. cv Diamante flowers, leaves and fruits at two maturity stages, Food and ChemicalToxicology 2011, 1549-1555

19. Ojewole J. "Hypoglycaemic and hypotensive effects of Psidiumgajava Linn. (Myrtaceae) leaf aqueous extract."Clin Pharmacol. 2005, 27, 259-689.

20. Okwu D and Josiah C, "Evaluation of the chemical composition of two Nigerian medicinal plants." African Journal of Biotechnology 2006, $5,4,357-361$.

increased oxalate and calcium level in kidney. ${ }^{65} \mathrm{Co}$ number and size of calcium oxalate deposits in different parts of the renal tubules and also prevented damages to is further supported by the evidence that natural flavanoids have been reported to exhibit anti-inflammatory and administration of the flavanoid rich fraction of Citrus medica unripe fruits viz. FFCM-2 $(380 \mu \mathrm{g} / \mathrm{kg}$, p.o.) and FFCM-3 $(440 \mu \mathrm{g} / \mathrm{kg}$, p.o.) to rats with ethylene glycol
induced lithiasis, reduced and prevented the growth of urinary stones, supporting folk information regarding
antiurolithiatic activity of the plant. The mechanism underlying this effect is still unknown, but is apparently concentrations of stone forming constituents and increase
conted to increased diuresis, lowering of urinary in inhibitors level, which may be ultimately responsible for decreased oxidative stress and decreased impairment of

These effects conclude the antiurolithiatic property of ACKNOWLEDGEMENTS

The author would like to thank Anand pharmacy college,
Anand, India for providing necessary facilities and special thanks to Prof. Tejal R. Gandhi (Principal, Anand pharmacy college, Anand, India), Dr. Kirti V. Patel
(H.O.D. , Pharmacology Department, Anand pharmacy college, Anand, India), Dr, Kalpana G. Patel (H.O.D. , Q.A. Department, Anand pharmacy college, Anand, India), Ku mar N. Fadadu for their guidance. 
21. Harborne JB, "phytochemical method: A Guide to modern techniques of plant analysis", Chapman and Hall, New York, 2nd edition 1984, 85. (Modified method)

22. 3TLC PlatePreparation, Jan 2011, http://www.socal-diybio.org/ 320

23. Pavia D, Lampman G, Kriz G, and Engel R, "Introduction to Organic Laborat oryT echniques: A Microscale Approach." 1999, 5-6

24. Male Z, Medic-saric M and Plana J, "Chromatography techniques." Pharmaactor, 1999, 345-349

25. Boyer R, "Isolation and Spectrophotometric Characterization of Photosynthet icPigments", Biochemical Education 1990

26. Karadi R, Gadge N, Alagawadi K and Savadi R, "Effect of Moringa oleifera Lam. root-wood on ethylene glycol induced urolithiasis in rats. Journal of Ethnopharmacology.'2006, 105, 306-311.

27. Lee Y, Huang W, Chang L, Chen M and Huang J, “Uninephrectomy enhancesurolithiasis in ethylene glycol treated rats." Kidney International 1992, 294

28. Stalikas C, "Extraction, separation, and detection methods for phenolic acids and

flavonoids.” J. Sep. Sci. 2007, 30, 3268-3295.

29. Mustafa M and Medeiros D, "Proximate compostition, mineral content and fattyacids of cat fish (Ictaluruspunctatusrafinesque) for different seasons and cookingmethods." J Food Sci1985, 50, 585-588

30. Hodgkinson A. and Williams A., "An improved colorimetric procedure for urineoxalate." ClinChimActa.1972, 16, 127-132

31. Fiske C and Subbarow Y, "The colorimetric determination of phosphate", Journalof Biological Chemistry 1925, 66,.375-381

32. Caraway W. and Seligson D., "Uric acid: Standard methods in clinicalchemistry.",Academic Press 1963, 4, 239-244

33. Green M, Hatch M. and Freel R.W., "Ethylene glycol induces hyperoxaluriawithout metabolic acidosis in rats", Am J Physiol Renal Physiol, April, 2005,536-543

34. Raghuramulu N., Madhavan N and Kalyanasundaram S, “A Manual of LaboratoryTechniques", National Institute of Nutrition, Hyderabad 1983,34

35. Robertson WG, Peacock M and Nordin DEC, "Calcium crystalluria in recurrent renal stone formers" Lancet. 1969, 2, 21-23.

36. Nishiura J.L., Campos A.H., Boim M.A., Hilberg I.P., and Schor N., "Phyllanthusniruri normalizes elevated urinary calcium levels in calcium stone formingpatients."Urology Res. 2004, 363

37. Chow F, Dysent I, Hamer D and Udall H, "Control of oxalate urolithiasis bydlalanine.”,Investigative Urology, 1975, 13, 113-117

38. Farooq S, Asokan D., Kalaiselvi P., SakthivelR.andVaralakshmi P.,"Prophylactic role of phycocyanin: a study of oxalate mediated renal cell injury",Chemico-Biological Interactions 2004, 149, 1-7

39. Vermeulen C, "Experiments on causation of urinary calculi." In: Essays inExperimental Biology, University of Chicago Press, Chicago1962, 253-269.

40. Prasad K, Bharathi K and Srinivasan K, "Evaluation of Musa (parasidicaLinnCultivar)-"Puttubale" stem juice for antilithiatic activity in albino rats." IndianJournal of Physiology and Pharmacology 1993, 37, 337-341

41. Khan SR, "Animal models of kidney stone formation: an analysis." World J Urol. 1997, 15, 236-243.

42. Green ML, Hatch M and Freel RW, "Ethylene glycol induces hyperoxaluria without metabolic acidosis in rats." Am J Physiol Renal Physiol. 2005, 289, 536-543.

43. Khan SR, "Experimental calcium oxalate nephrolithiasis and the formation of human urinary stones." Scanning Microsc. 1995, 9, 89-100. 44. Atmani F, Slimani Y, Mimouni M, Hacht B "Prophylaxis of calcium oxalate stones by Herniaria hirsuta on experimentally induced nephrolithiasis in rats." British Journal of Urology International 2003,92,137-140

45. Huang HS, Ma MC, Chen J, Chen CF "Changes in the oxidantantioxidant balance in the kidney of rats with nephrolithiasis induced by ethylene glycol." Journal of Urology2002, 167, 2584-2593
46. Selvam P, Kalaiselvi P, Govindaraj A, Murugan VB, Sathishkumar AS "Effect of A. lanata leaf extract and vediuppu chunnam on the urinary risk factors of calcium oxalate urolithiasis during experimental hyperoxaluria."Pharmacological Research 2001,43,89-93

47.Lieske JC, Swift H, Martin T " Renal epithelial cells rapidly bind and internalize calcium oxalate monohydrate crystals.” Proc Natl Acad Sci USA1994, 91,6987-91

48. Atmani F, Lacour B, Jungers P and Drueke T, "Reduced inhibitory activity of uronic acid-rich protein in urine of stone formers." Urol Res. 1994, 22, 257-260.

49. Maurice A, Erick L "Hypercalciuria. "Joint Bone Spine2000, 67(6),509-515

50. Roger K, Low MD, Stoller ML “ Uric acid nephrolithiasis.” Urologic Clinics of North America 1997,24,135-148

51. Selvam R, Kalaiselvi P, Govindaraj A, Balamurugan V and Kumar AS, "Effect of Aerva lanata leaf extract and vediuppuchunnam on the urinary risk factors of calcium oxalate urolithiasis during experimental hyperoxaluria."Pharmacol. Res. 2001, 43, 89-93.

52. Yadav RD, Jain SK, Alok S, Mahor A, Bharti JP and Jaiswal M, "herbal plants used in the treatment of urolithiasis: a review" IJPSR, 2011, 1412-1420.

53. Jie F, Michael AG, Paramjit SC “ Impact of ammonium chloride administration on a rat ethylene glycol urolithiasis model." Scanning Microscopy1999, 13(2-3),299-306

54. Ringold S, Tiffany JG, Richard M “ JAMA-Kidney stones" 2005,293(9), 1158

55. Kok DJ, Papapoulos SE, Bijvoet OL " Excessive crystal agglomeration with low citrate excretion in recurrent stone-formers." Lancet 1986,1,1056-1058

56. Stitchantrakul W, Kochakaran W, Ruangraksa C, Domrongkitchaiporn S "Urinary risk factors for recurrent calcium stone formation in Thai stone formers." J Med Assoc Thai. 2007,90(4),688-98 57. Saunders T, Magnesium Magic, www.sunriseherbshop.com.

58. Yuji K, Satoshi Y, Sunao Y, Shusaku N, Jun-ichi H, Naoki W, Kyokushin $\mathrm{H}^{\text {" }}$ Changes in urinary parameters after oral administration of potassium-sodium citrate and magnesium oxide to prevent urolithiasis." Urology 2004,63(1),7-11

59. Desmars JF, T awashi R “ Dissolution and growth of calcium oxalate monohydrate." I. Effect of magnesium and $\mathrm{pH}$. Biochim Biophys Acta 1973,313,256-67

60. Robertson WG " Measurement of ionized calcium in biological fluid.” Clin Chim Acta 1969,24,149-57

61. Reungjui S, Prasongwatana V, Premgamone A “ Magnesium status of patients with renal stone and its effect on urinary citrate excretion." BJU int 2002,90,635-639

62. Ghodkar PB, "Chemical Tests in Kidney Disease. In: Textbook of Medical Laboratory Technology.” Sood, M.S. (Ed.). Bhalani Publishing House, Mumbai, 1994, 118.

63. Tatiya AU, Desai DG, Surana SJ and Patil PH, "Anti inflammatory and nitric oxide scavenging activity of roots of Eranthemumroseum." Indian Drugs. 2007, 44, 815-818.

64. Borg DC, Schaich KM, Elmore JJ and Bell JA, Photochem. Photobiol.1978, 28, 887.

65. Divakar K, Pawar AT, Chandrasekhar SB, Dighe SB and Divakar G, "Protective effect of the hydro-alcoholic extract of Rubia cordifolia roots against ethylene glycol induced urolithiasis in rats." Food and Chemical Toxicology. 2010, 48, 1013-1018.

66. Ravanan P, Singh SK, Rao GS and Kondaiah P, "Grouth inhibitory, apoptotic and anti-inflammatory activities displayed by a novel modified triterpenoid, cyano enone of methyl boswellat es." MS.201 1,26,245-256. 67. Sayyah M., Hadidi N and Kamalinejad M, "Analgesic and antiinflammatory activity of Lactuca sativa seed extract in rats." Journal of Ethnopharmacology. 2004, 92, 325-329. 